\title{
Therapeutic effect of Ziziphus lotus honey on hard palate ulcers in rats
}

\section{Lecznicze działanie miodu z głożyny afrykańskiej (Ziziphus lotus) na owrzodzenia podniebienia twardego u szczurów}

\author{
Leila Golpasandhagh ${ }^{1}$, Parvin Salehi ${ }^{1}$, Babak Karimi², Eskandar Moghimipour ${ }^{3}$ \\ ${ }^{1}$ Department of Periodontology, School of Dentistry, Ahvaz Jundishapur University of Medical Sciences, Ahvaz, Iran \\ 2Department of Pathology, School of Dentistry, Ahvaz Jundishapur University of Medical Sciences, Ahvaz, Iran \\ ${ }^{3}$ Medicinal Plant Research Centre, Ahvaz Jundishapur University of Medical Sciences, Ahvaz, Iran
}

Key words: honey, palatal wound healing, histological analysis.

Słowa kluczowe: miód, gojenie ran na podniebieniu, analiza histologiczna.

\begin{abstract}
Aim of the research: The aim of the study was to assess the effect of honey gel on the hard palate wound healing process in rats.

Material and methods: In this interventional study, a total of 60 rats were randomly divided into 4 groups $(n=15)$ including a control group, a honey gel group, a polyethylene glycol base group, and an oral honey group. Oral wounds were created $(4 \times 6 \mathrm{~mm})$ on the anterior palatal rugae, and after $24 \mathrm{~h}$ the wounds were rinsed with normal saline solution and the studied groups were treated by topical application of honey gel, polyethylene glycol base, and oral honey. On days 3, 7, and 14, five rats from each group were euthanized and histological samples were prepared, and the tissue slides were stained with haematoxylin eosin and observed under a light microscope. The mean number of neutrophils, fibroblasts, macrophage and blood vessel count, epithelialization, and the density of collagen fibres of each sample were assessed. Data were analysed using ANOVA and Kruskal-Wallis Test.

Results: The number of blood vessels and the density of collagen fibres on day 14 were significantly higher in the honey gel group than in the control group $(p<0.05)$. The number of blood vessels and the rate of epithelialization on day 14 were significantly increased in honey gel group compared to basal group $(p<0.05)$. Other data were not statistically significant among the groups $(p>0.05)$.
\end{abstract}

Conclusions: Topical application of honey gel can accelerate the wound healing process of the hard palate.

\section{Streszczenie}

Cel pracy: Ocena wpływu żelu zawierającego miód na proces gojenia się ran w obrębie podniebienia twardego u szczurów. Materiał i metody: W ramach badania interwencyjnego 60 szczurów zostało losowo podzielonych na 4 grupy $(n=15)-$ grupę kontrolną i grupy, w których stosowano żel z dodatkiem miodu, bazę z glikolu polietylenowego oraz miód podawany doustnie. U szczurów sztucznie wytworzono rany $(4 \times 6 \mathrm{~mm})$ na przednich fałdach podniebiennych. Po 24 godzinach rany przepłukano roztworem soli fizjologicznej, a w badanych grupach wprowadzono leczenie miejscowe przy użyciu żelu z miodem, bazy z glikolu polietylenowego i podawanego doustnie miodu. W dniach 3., 7. i 14. po pięć szczurów z każdej grupy poddano eutanazji i opracowano próbki histologiczne. Preparaty tkankowe wybarwiono hematoksyliną oraz eozyną i poddano obserwacji pod mikroskopem świetlnym. Analizowano średnią liczbę neutrofilów, fibroblastów i makrofagów, a także liczbę naczyń krwionośnych, proces nabłonkowania (epitelializacji) oraz gęstość włókien kolagenowych w każdym preparacie. Dane analizowano za pomocą testu ANOVA i testu Kruskala-Wallisa.

Wyniki: W 14. dniu badania liczba naczyń krwionośnych i gęstość włókien kolagenowych były istotnie wyższe w grupie leczonej żelem zawierającym miód niż w grupie kontrolnej $(p<0,05)$. Ponadto w grupie leczonej żelem z dodatkiem miodu większa była liczba naczyń krwionośnych i szybkość procesu nabłonkowania w 14. dniu badania w porównaniu z grupa kontrolną $(p<0,05)$. Dla pozostałych danych nie uzyskano statystycznie istotnych różnic pomiędzy grupami $(p>0,05)$. Wnioski: Miejscowe stosowanie żelu zawierającego miód może przyspieszać proces gojenia ran w obrębie podniebienia twardego. 


\section{Introduction}

Autogenous free grafts are still considered as the gold standard for gingival augmentation procedures that are used to increase tissue thickness, achieve complete root coverage, and prevent gingival recession [1]. In this technique, the palate, as the most common transplant donor site, is left as an open wound to be healed by second intention [2]. Various dressing materials have been used to target oral ulcers, i.e. alleviate postoperative pain and prevent infection. These materials may have deleterious effects on oral tissues and can cause adversative tissue reaction (e.g. toxicity, allergic reaction) [3].

Honey has been used as a treatment for wound healing and other health conditions for thousands of years. In recent years, honey has been re-focused on wound care because honey is capable of blocking bacterial communication, so bacteria are incapable of developing a resistance to honey [4].

Honey has been recognized for its antibacterial, anti-inflammatory, anti-allergic, antithrombotic, and vasodilatory action and wound healing properties. It also has no harmful effects on tissues due to the source of antioxidant substances and flavonoids [5]. It has been suggested that honey accelerates wound healing due to its chemical and anti-inflammatory debridement function and prevents the invasion of microorganisms owing to the ability to form a viscous barrier on the wound surface [6].

Honey contains a variety of components, mainly sugars: $2 \%$ fructose, $2 \%$ glucose, and $2 \%$ maltose, along with other components such as oligosaccharides, minerals, carbohydrates, and enzymes, and phytochemicals such as flavonoid, ferulic acid, and caffeic acid. The specific structure of any honey is subject to the flowers available to the bees $[7,8]$.

Studies have shown the beneficial effects of honey on the prevention and reduction of various oral diseases [9]. The antibacterial effect of honey on 60 species of oral cavity bacteria has been identified; one of them is Streptococcus mutans, a bacterium associated with dental caries, and honey prevents bacterial resistance $[10,11]$. Honey has been shown to be effective in inhibiting and reducing dental plaque formation [12], gingivitis [13, 14], and halitosis [15]. Various studies have shown that honey is effective in delaying, preventing, and reducing radiation-induced mucositis $[16,17]$ and xerostomia [18] in patients undergoing radiotherapy for head and neck cancer. Recent research has shown that Tualang honey has a potent antiproliferative effect on oral squamous cell carcinoma [19].

\section{Aim of the research}

The aim of the present study was the assess the effect of honey gel on the hard palate wound healing process in rats.

\section{Material and methods}

In the present interventional study, a total of 60 adult female Wistar rats weighing $200 \pm 10$ g were obtained from the Animal Reproduction Centre of Ahvaz Jundishapur University of Medical Sciences (AJUMS). The rats were kept in special metal cages (5 per cage) at appropriate temperature and humidity, and in 12-hour light-dark conditions. All the rats were divided into 12 groups of 5 including a normal saline group (3, 7, and 14 days), a honey gel group (3, 7, and 14 days), a basal group (3, 7 , and 14 days), and an oral honey group $(3,7$, and 14 days).

The honey sample used in this study was Lotus Honey, which is a nectar of the Ziziphus shrub that is widely distributed in southern and warm regions of Iran. Chemical experiments required for honey quality assessment were performed in the Vice-Chancellor of Food and Drugs Affairs laboratory of AJUMS. The quality of honey was desirable and in accordance with national standards of Iran. For more honey retention on the wound site polyethylene glycol micellar adhesive was used as a gel base, then $20 \%$ of polyethylene glycol and $80 \%$ of honey were mixed using a mechanical stirrer. The compound was stored for $24 \mathrm{~h}$ to 1 week at laboratory temperature for dephasing analysis. The prepared compound (honey gel) was not dephased during this period and was ready for study.

The rats were laid in supine position and general anaesthesia was performed through injection of ketamine $(75 \mathrm{mg} / \mathrm{kg})$ and xylazine $(5 \mathrm{mg} / \mathrm{kg})$. The animal's mouth was fully opened through the insertion of 2 nylon loops in the maxillary and mandibular central incisors and immediately on the back of the incisive papilla, 2 palatal rugae were transversely cut (size $=4 \times 6 \mathrm{~mm}$, thickness $=1-2 \mathrm{~mm}$ ) from the hard palate surface using \#15 scalpel blades and removed after separation. The bleeding caused by this incision was controlled by packing a sterile cotton swab on the base of the wound bed. After $24 \mathrm{~h}$, the wounds were cleansed with sterile saline. The treatment was started in the studied groups as follows: group $1(n=3)$ : physiological serum treatment, group $2(n=3)$ : topical honey gel application in the wound site, group 3 $(n=3)$ : basal treatment alone in the operative position, and group $4(n=3)$ : oral honey treatment.

All treatments were repeated 3 times daily. In the treatment process, the rats were exposed to topical application of $0.1 \mathrm{ml}$ of honey gel and $0.1 \mathrm{ml}$ of basal using a swap. In the oral honey group, $0.1 \mathrm{ml}$ of oral honey was poured into the mouth of the target group using a syringe. In the normal saline group, the wound was irrigated with $0.1 \mathrm{ml}$ of normal saline solution. Up to $2 \mathrm{~h}$ after treatment, the rats were not allowed to access to food and water. The euthanasia was carried out (3-day groups on day 3, 7-day groups on day 7 , and 14-day groups on day 14) through over-injection of ketamine hydrochloride and cervical dislo- 
cation. The specimens were prepared for histopathological examination and fixed in $10 \%$ formalin. The prepared blocks were then washed and dehydrated in alcohol and then immersed in paraffin. From each sample, 5 to 6 sections (5-6 $\mu \mathrm{m}$ thick) were prepared and stained with haematoxylin eosin.

For histological examination, high-quality tissue slides were prepared from each specimen section. The slides were observed under a light microscope by a trained pathologist blinded to the specimens (4 fields were randomly selected on $400 \times$ magnification). Then, neutrophil, macrophage, blood vessels, and fibroblast cells were counted in these 4 fields, and the mean of each was recorded separately for each group on different days. The ratio of epithelialization compared to the total volume of the cells of the epithelium cells lost in wound surface was documented. Also, to determine the amount of collagen fibre accrued in the wound area, the density of strands was documented visually in 3 degrees: $(0=$ no collagen fibres), one ( 1 = low density), ( 2 = medium density), and $(3=$ high density).

\section{Statistical analysis}

Data were analysed using ANOVA, Kruskal-Wallis tests, and SPSS version 18.

\section{Results}

The results of the mean and standard deviation of neutrophil, macrophage, fibroblast, blood vessels, collagen fibre density, and ratio of epithelialization are described in detail:

1) The number of neutrophil cells was high in all groups on day 3 and gradually decreased on day 7 . The reduction of neutrophils on the $7^{\text {th }}$ day compared to the $3^{\text {rd }}$ day was statistically significant in the control group ( $p=0.001)$, the honey gel group $(p=0.04)$, and the oral honey group $(p=0.04)$. The decrease in the neutrophil cell counts was continued from day 7 to day 14, but reduction in the basal group was significant ( $p=0.03)$. No significant difference was found between group $3(p=0.39)$, group $7(p=0.07)$, and group $14(p=0)$ (Table 1$)$.

2) Macrophage cells had the highest number on day 3 and gradually decreased from day 3 to day 7; the reduction was significant only in the oral honey group $(p=0.02)$. The decrease in the macrophage cell number was continued from day 7 to day 14, and this decrease was significant only in the control group $(p=0.02)$. Nevertheless, no significant difference was found among groups on the $3^{\text {rd }}$ day $(p=0.4), 7^{\text {th }}$ day $(p=0.82)$, and $14^{\text {th }}$ day $(p=0.58)$ (Table 1).

Table 1. Mean and standard deviation of variables

\begin{tabular}{|c|c|c|c|c|}
\hline \multirow[t]{2}{*}{ Variable } & \multirow[t]{2}{*}{ Groups } & \multicolumn{3}{|c|}{ Mean \pm SD } \\
\hline & & Third day & Seventh day & Fourteenth day \\
\hline \multirow{4}{*}{$\begin{array}{l}\text { Fibre density } \\
\text { Collagen }\end{array}$} & Control & $0.4 \pm 0.5$ & $0.8 \pm 0.83$ & ${ }^{*} 2 \pm 0^{*}$ \\
\hline & Honey gel & $0.6 \pm 0.548$ & $1.80 \pm 1.09$ & $* 3 \pm 0^{*}$ \\
\hline & Edible honey & $0.2 \pm 0.44$ & $1.80 \pm 1.09$ & $2.6 \pm 0.54^{*}$ \\
\hline & Base & $0.4 \pm 0.54$ & ${ }^{\star} 1.40 \pm 0.89$ & $2.60 \pm 0.54$ \\
\hline \multirow[t]{4}{*}{ Neutrophil } & Control & $8 \pm 5.70$ & $0.10 \pm 1.30^{*}$ & $1.0 \pm 0.22$ \\
\hline & Honey gel & $3 \pm 40$ & $0.10 \pm 1.30^{*}$ & $1.0 \pm 0.15$ \\
\hline & Edible honey & $22 \pm 32.71$ & $0.40 \pm 0.89^{*}$ & $0.30 \pm 0.44$ \\
\hline & Base & $12 \pm 10.36$ & $10.80 \pm 13.46$ & $1.3 \pm 22.51^{\star}$ \\
\hline \multirow[t]{4}{*}{ Macrophage } & Control & $7.60 \pm 12.70$ & $7 \pm 3.16$ & $1.40 \pm 1.51^{\star}$ \\
\hline & Honey gel & $5.60 \pm 3.78$ & $3.8 \pm 2.38$ & $1 \pm 1.23$ \\
\hline & Edible honey & $14 \pm 17.46$ & $5.6 \pm 2.6^{\star}$ & $1 \pm 1.02$ \\
\hline & Base & $7 \pm 4.47$ & $4.80 \pm 3.27$ & $2.20 \pm 2.86$ \\
\hline \multirow[t]{4}{*}{ Fibroblasts } & Control & $5.20 \pm 5.40$ & *18 184.90 & *58 \pm 24.90 \\
\hline & Honey gel & $11.80 \pm 6.34$ & $\star 56 \pm 23.02$ & $74 \pm 26.07$ \\
\hline & Edible honey & $11 \pm 7.41$ & $\star 30 \pm 18.37$ & *58 \pm 24.90 \\
\hline & Base & $11.80 \pm 10.45$ & $* 43.60 \pm 25.39$ & $74 \pm 16.73$ \\
\hline \multirow[t]{4}{*}{ Blood vessels } & Control & $3.6 \pm 4.03$ & $4.80 \pm 1.7$ & *4.48 \pm 54 \\
\hline & Honey gel & $4 \pm 6.24$ & $7.50 \pm 5.29^{*}$ & ${ }^{\star} 9.2 \pm 3.12$ \\
\hline & Edible honey & $2.9 \pm 3.97$ & $5.6 \pm 3.78$ & $6.60 \pm 3.2$ \\
\hline & Base & $2 \pm 1$ & $7.50 \pm 5.29^{\star}$ & *4.8 \pm 1.09 \\
\hline \multirow[t]{4}{*}{ Epithelialization } & Control & 0 & $30 \pm 4.47^{*}$ & *84 \pm 16.15 \\
\hline & Honey gel & $4.47 \pm 2$ & $50 \pm 4.18^{*}$ & ${ }^{*} 100 \pm 00^{*}$ \\
\hline & Edible honey & 0 & $23.40 \pm 42.98^{\star}$ & ${ }^{*} 92 \pm 10.95$ \\
\hline & Base & 0 & $38.20 \pm 38.09^{*}$ & *58 \pm 39.62 \\
\hline
\end{tabular}


3) The number of blood vessels in all groups increased from day 3 to day 7 , and this increase was significant in the honey gel $(p=0.01)$ and basal $(p=0.02)$ groups. The number of blood vessels was decreased in the control and basal groups from the $7^{\text {th }}$ to the $14^{\text {th }}$ day, but this decrease was not statistically significant $(p>0.05)$. However, the number of blood vessels in the honey gel and oral honey groups increased from day 7 to day 14 , but this increase was not statistically significant $(p>0.05)$. The number of blood vessels on the $3^{\text {rd }}(p=0.88)$ and $7^{\text {th }}(p=$ 0.87 ) days was not statistically significant among the groups. On the $14^{\text {th }}$ day, there was a statistically significant difference among the groups $(p=0.01)$ : in the honey gel group, the number of blood vessels was significantly higher than the basal group $(p=0.03)$, and blood vessels in the honey gel group showed a statistically significant increase $(p=0.02)$ compared to the control group (Table 1).

4) The number of fibroblast cells increased from day 3 to day 7, and this increase was significant in all groups. The number of fibroblast cells was increased from day 7 to day 14 in all groups, and this increase was significant in the control group $(p<0.004)$, the oral honey group $(p<0.03)$, and the basal group $(p<0.02)$. The number of fibroblast cells gradually increased during the $3^{\text {rd }}, 7^{\text {th }}$, and $14^{\text {th }}$ days. There was no significant difference in the number of fibroblast cells between the $3^{\text {rd }}$ day $(p<0.47), 7^{\text {th }}$ day $(p<0.09)$, and $14^{\text {th }}$ day $(p<0.58)$ (Table 1 , Figure 1$)$.

$5)$ The rate of epithelialization increased from day 3 to day 7 in all groups, and this increase was statistically significant in all groups. The rate of epithelialization increased from day 7 to day 14 and was significant in the control $(p<0.02)$, honey gel $(p<0.01)$, and oral honey $(p<0.04)$ groups, but this increase was not significant in the basal group $(p<0.2)$. There was no significant difference in the percentage of epithelialization between the $3^{\text {rd }}(p<0.41)$ and $7^{\text {th }}(p<0.20)$ day groups. Howev-

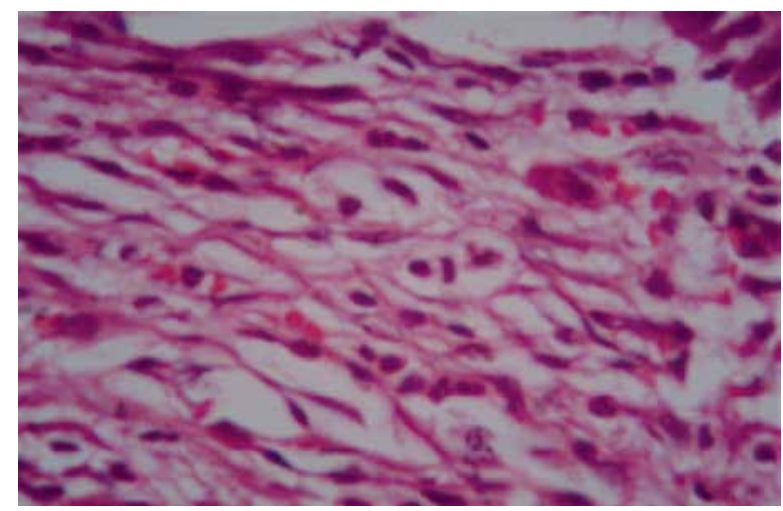

Figure 1. Microscopic view of the honey gel group on the seventh day shows high levels of collagen and fibroblast cells er, on the $14^{\text {th }}$ day, the amount of epithelialization in the honey gel group was significantly higher than in the basal group $(p<0.03)$, and there was no significant difference among other groups on the $14^{\text {th }}$ day (Table 1$)$.

6) The rate of collagen fibres increased gradually from the $3^{\text {rd }}$ day to the $7^{\text {th }}$ day in all groups, and this increase was only statistically significant in the honey gel $(p<0.04)$ and oral honey $(p<0.01)$ groups (Figure 2$)$. The extent of collagen fibres increased significantly from the $7^{\text {th }}$ to the $14^{\text {th }}$ day in all groups. There was no statistically significant difference between the $3^{\text {rd }}$ and $7^{\text {th }}$ day groups $(p>0.05)$. On the $14^{\text {th }}$ day, the increase in collagen fibre content in the honey gel group compared to basal group was statistically significant $(p<0.04)$. There was no significant difference between the other groups $(p>0.05)$ (Table 1).

\section{Discussion}

The topical application of honey for wound healing dates back to ancient civilizations [20]. The wound healing properties of honey cause wound contraction, granulation tissue formation, and improvement of epithelialization. Also, it affects stimulation of tissue growth and collagen production, stimulation of new blood vessel formation in the wound bed, and reduction of oedema inflammation and pain [21, 22].

Oral ulcers in the free gingival graft (FGG) donor site can be painful and interfere with oral function. The treatment and management of oral ulcers in the donor site are very important; however, many medical and palliative treatments such as the use of periodontal dressings and acrylic stents can target these ulcers [2]. Nevertheless, newer, affordable, easier, and more accessible treatments are required [5].

The aim of the present study was histological evaluation of the effect of honey gel on the hard palate wound healing process in rats. In this study, histo-

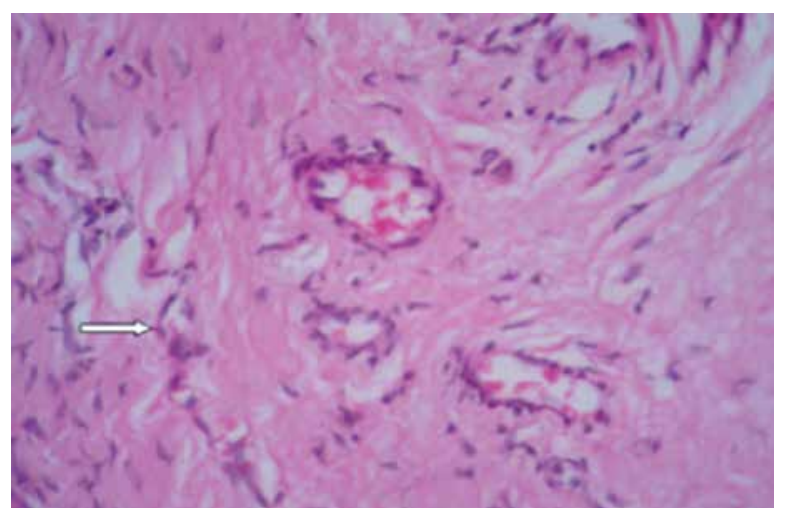

Figure 2. Microscopic view of the honey gel group on the fourteenth day shows abundant fibroblast cells (white arrows) and dense collagen filament 
pathological evaluation of the effect of honey gel on oral ulcer healing due to removal of soft tissue of the palate for free gingival graft was assessed. The results of this study showed that the number of blood vessels and the density of collagen fibres on day 14 were significantly higher in the honey gel group than in the control group $(p<0.05)$. The number of blood vessels and the rate of epithelialization on day 14 were significantly increased in the honey gel group compared to the basal group $(p<0.05)$. Other data were not statistically significant among the studied groups.

Many studies have reported the anti-inflammatory activity of honey [23]. In this study, the number of neutrophils in different groups on days 3, 7, and 14 was not statistically significant; however, on the $3^{\text {rd }}$ day the number of neutrophils in the honey gel group was lower than in the other groups. The number of macrophage cells in different groups was not statistically significant, but the number of macrophages on days 3 and 7 was lower in the honey gel group than in the other groups.

Neutrophil is one of the first-responders of inflammatory cells migrating towards the site of inflammation by engulfing and killing bacteria [24]. Neutrophils have high phagocytic properties and are critical for wound healing, although neutrophils are not normally observed in normal skin [25]. Honey, due to its antimicrobial properties, can reduce the microbial load of the wound and reduce the neutrophil numbers on the site of the wound [26].

Macrophages react to neutrophils and can induce apoptosis in neutrophils [27]. In the present study, the number of neutrophils in the honey gel group was lower than in the other groups. The reason could be the appearance of low levels of macrophages and neutrophils in the tissue. In the healing stage, the number of macrophages progressively decreased.

In the Chamani et al. study, the inflammation mean rank was statistically lower in the honey group [5]. Also, the result of Nazeri et al.'s study showed that honey-based alginate hydrogel on the $21^{\text {st }}$ day had the lowest inflammation, which was consistent with the result of the present study [8].

Nakajima et al., 2013, in a study showed that the number of neutrophils in the treatment honey group on days 3 and 7 was similar to the control group, which was inconsistent with the results of the present study [28], as well as the results of the Haryanto et al. study, suggesting that the topical use of Indonesian honey on the site of cutaneous wounds increased the number of neutrophils on days 3 and 7 in the wound area [29]. These differences could be explained by the different properties of honey from different sources as well as the location of the wound.

Macrophages are able to promote wound re-epithelialization by fibroblast growth factor (FGF-2) and endothelial vascular growth factor (EGF-2), and stim- ulate collagen synthesis in human fibroblasts [30]. Honey can stimulate the production of TNF- $\alpha$ from macrophage (stimulates TNF- $\alpha$ secretion from macrophage) [31].

In the present study, although the number of macrophages in the honey gel group on the third day was lower than the other groups, the number of fibroblasts and collagen fibres in the honey gel group on days 3 , 7 , and 14 were higher than the other groups. However, only the ratio of collagen fibres on day 14 was significantly different between the honey gel and control groups.

The lower number of macrophages in the honey gel group and the higher number of fibroblasts and the ratio of collagen fibres can be related to the higher activity of the honey gel macrophages which produce the cytokines necessary for fibroblast maturation and promote collagen production by fibroblasts. Collagen synthesis requires energy, which is provided by the sugar present in honey. The glycolysis pathway is a pathway for producing energy required for fibroblasts to produce and synthesize collagen [29].

Nisbet et al., 2010, in their study showed that the number of macrophages in the wound area was statistically higher than in the control group only on day 7 , and the number of fibroblasts and collagen fibres were higher in the honey groups than in the control group [32].

In the study of Nakajima et al., the number of macrophage cells on days 3 and 7 in all 3 Japanese honey species was similar to the control group. The number of myofibroblast cells on day 7 and the ratio of collagen fibres on day 7 were lower in the honey groups than in the control group. The reason for the decrease in myofibroblast cells and collagen fibres was explained by the lower number of macrophages that produced less inflammatory cytokines for myofibroblast activation [28].

Many researchers have shown that honey stimulates new blood vessel formation in the wound bed [33-37]. Hydrogen peroxide is a topical antiseptic substance that in low concentrations stimulates angiogenesis and fibroblast growth. Honey stimulates slow-release of low $\mathrm{H}_{2} \mathrm{O}_{2}$ concentration [8]. In the present study, the number of blood vessels in all groups increased gradually from day 3 to day 7 , but this increase was not statistically significant. However, the highest rate of angiogenesis was observed in the honey gel group. In the honey gel group, the angiogenesis trend was continued, and on the $14^{\text {th }}$ day a statistically significant difference was found between the honey gel group and the polyethylene glycol base group, i.e. the number of blood vessels in the honey gel group was significantly higher than in the base group.

Platelets release inflammatory cells and mostly macrophages and fibroblasts reside in angiogenic factors such as vascular endothelial growth factor 
(VEGF), which plays a crucial role in the stimulation of angiogenesis (during tissue maturation the number of blood vessel cells decreases due to decreased or no angiogenic stimulation) [38]. In the present study, in the honey gel group, the number of blood vessels increased until day 14. This indicates that the process of blood vessel depletion was delayed in the honey gel group compared to the other groups. This could be explained by the presence of more angiogenic cytokines in the wound site, which decreased the process of reducing the number of blood vessels in the wound site.

Nazeri et al., 2015 showed that angiogenesis on day 7 and fibroblasts on day 14 were higher in honey-based alginate hydrogel than in other groups, which was in line with the results of the present study $[7,8]$. The result of the study by Nisbet et al. showed that angiogenesis and fibroplasia were higher in the honey-treated groups on day 7 , and in the rhododendron honey group on day 14 they were higher than in other groups [32].

Epithelialization is one of the major factors in wound healing [29]. In the present study, the rate of re-epithelialization on days 3 and 7 among the groups was not statistically significant. However, the rate of epithelialization in the honey gel group was higher than in other groups on days 3, 7, and 14 and reached 100\% (complete epithelialization) on day 14 . On day 14 , the re-epithelialization was significantly higher in the honey group than in the basal group. This suggests that the increase in the rate of re-epithelialization in the honey gel group was only related to the positive effect of honey on the epithelialization process, not the polyethylene glycol base.

The result of the study by Gill et al. showed that complete epithelization was managed 2 days earlier than the normal epithelization time in the manuka group, and histopathological analysis showed wellformed keratinized squamous epithelium [22]. Chamani et al., 2017, in a study concluded that re-epithelialization on days 4,6 , and 8 was significantly higher in the honey group than in the control group, i.e. fast re-epithelialization occurred in the honey group. Also, the granulation tissue formation mean rank on days 4 and 8 in the honey group was higher than in the control group, which was consistent with the results of the present study [5].

Nakajima et al., 2013, suggested that the ratio of wound re-epithelialization in Japanese honey (Yamada Bee Farm, Okayama, Japan) was reduced compared to hydrocolloid dressing. This property of Japanese honey was different from honeys studied in other countries. This was attributed to different chemical compositions of honey, and it was recommended that Japanese honey be used only in the inflammatory phase that accelerates healing [28].

To achieve proper wound healing, honey must be present at the wound surface at all times, to induce anti-inflammatory, antibacterial, and immune-stimulating activity. Data have clearly indicated that honey had no local or systemic adverse effects (allergy or toxicity) [21].

Honey types are not the same. Each honey has its own unique characteristics that include antimicrobial, antioxidant, anti-inflammatory, and wound healing properties [20].

The honey used in this study was Lotus honey, which is a nectar of the Ziziphus shrub (Ziziphus spp.) commonly grown in southern and warm regions of Iran. The results of this study showed that the natural honey of this area expedited the wound healing process.

The most significant limitation is testing the tissues of animals of one sex and one species, which may have an impact on the results obtained in other research material (e.g. in other mammals).

Because the present study was conducted on animals, it is recommended to use honey gel as a material to accelerate wound healing in gingival free graft in future human studies.

\section{Conclusions}

Topical application of honey gel can accelerate the wound healing process of the hard palate.

\section{Acknowledgments}

This study was supported by Ahvaz Jundishapur University of Medical Sciences

\section{Conflict of interest}

The authors declare no conflict of interest.

\section{References}

1. Wyrębek B, Górski B, Górska R. Patient morbidity at the palatal donor site depending on gingival graft dimension. Dental Med Problems 2018; 55: 153-159.

2. Nwman MG, Takei H, Klokkevold PR, Carranza FA. Newman and Carranza's Clinical Periodontology E-Book: Elsevier Health Sciences 2018.

3. Freedman M, Stassen LF. Commonly used topical oral wound dressing materials in dental and surgical practice - a literature review. Irish Med J 2013; 59: 190-195.

4. Clark M, Adcock L. Honey for Wound Management: A Review of Clinical Effectiveness and Guidelines [Internet]. Ottawa (ON): Canadian Agency for Drugs and Technologies in Health; 2018 Nov 6. Available from: https:// www.ncbi.nlm.nih.gov/books/NBK538361/.

5. Chamani G, Zarei MR, Mehrabani M, Mehdavinezhad A, Vahabian M, Ahmadi-Motamayel F. Evaluation of honey as a topical therapy for intraoral wound healing in rats. Wounds 2017; 29: 80.

6. Aziz Z, Hassan BAR. The effects of honey compared to silver sulfadiazine for the treatment of burns: a systematic review of randomized controlled trials. Burns 2017; 43: 50-57. 
7. Wahdan H. Causes of the antimicrobial activity of honey. Infection 1998; 26: 26-31.

8. Nazeri S, Ardakani EM, Babavalian H, Latifi AM. Evaluation of effectiveness of honey-based alginate hyrogel on wound healing in a mouse model of rat. J Appl Biotechnol Rep 2015; 2: 293-297.

9. Ramsay EI, Rao S, Madathil L, Hegde SK, Baliga-Rao MP, George T, Baliga MS. Honey in oral health and care: a mini review. J Oral Biosci 2019; 61: 32-36.

10. Beena JP, Sahoo P, Konde S, Raj NS, Kumar NC, Agarwal M. Manuka honey: a potent cariostatic agent - an in vitro study. Int J Clin Pediatr Dent 2018; 11: 105-109.

11. Asadi-Pooya AA, Pnjehshahin MR, Beheshti S. The antimycobacterial effect of honey: an in vitro study. Riv Biol 2003; 96: 491-495.

12. Nayak PA, Nayak UA, Mythili R. Effect of Manuka honey, chlorhexidine gluconate and xylitol on the clinical levels of dental plaque. Contemp Clin Dentistry 2010; 1 : 214-217.

13. Singhal R, Siddibhavi M, Sankeshwari R, Patil P, Jalihal S, Ankola A. Effectiveness of three mouthwashesManuka honey, Raw honey, and Chlorhexidine on plaque and gingival scores of 12-15-year-old school children: a randomized controlled field trial. J Indian Soc Periodontol 2018; 22: 34-39.

14. Atwa ADA, AbuShahba RY, Mostafa M, Hashem MI. Effect of honey in preventing gingivitis and dental caries in patients undergoing orthodontic treatment. Saudi Dental J 2014; 26: 108-114.

15. Drain J, Fleming MO. Palliative management of malodorous squamous cell carcinoma of the oral cavity with Manuka honey. J Wound Ostomy Continence Nurs 2015; 42: 190-192.

16. Rao S, Hegde SK, Rao P, Dinkar C, Thilakchand KR, George T, Baliga-Rao MP, Palatty PL, Baliga MS. Honey mitigates radiation-induced oral mucositis in head and neck cancer patients without affecting the tumor response. Foods 2017; 6: 77.

17. Charalambous M, Raftopoulos V, Paikousis L, Katodritis N, Lambrinou E, Vomvas D, Georgiou M, Charalambous A. The effect of the use of thyme honey in minimizing radiation-induced oral mucositis in head and neck cancer patients: a randomized controlled trial. Eur J Oncol Nurs 2018; 34: 89-97.

18. Charalambous A, Lambrinou E, Katodritis N, Vomvas D, Raftopoulos V, Georgiou M, Paikousis L, Charalambous $M$. The effectiveness of thyme honey for the management of treatment-induced xerostomia in head and neck cancer patients: a feasibility randomized control trial. Eur J Oncol Nurs 2017; 27: 1-8.

19. Ghashm AA, Othman NH, Khattak MN, Ismail NM, Saini R. Antiproliferative effect of Tualang honey on ora squamous cell carcinoma and osteosarcoma cell lines. BMC Complement Altern Med 2010; 10: 49.

20. Bogdanov S. Propolis. Composition, Health, Medicine A Review. Bee Product Science 2017; 1-28.

21. Al-Waili N, Salom K, Al-Ghamdi AA. Honey for wound healing, ulcers, and burns; data supporting its use in clinical practice. TheScientificWorldJournal 2011; 11: 766-787.

22. Gill R, Poojar B, Bairy LK, Praveen KS. Comparative evaluation of wound healing potential of manuka and acacia honey in diabetic and nondiabetic rats. J Pharm Bioallied Sci 2019; 11: 116-126.
23. Rao PV, Krishnan KT, Salleh N, Gan SH. Biological and therapeutic effects of honey produced by honey bees and stingless bees: a comparative review. Rev Brasil Farmacogn 2016; 26: 657-664.

24. George Broughton I, Janis JE, Attinger CE. Wound healing: an overview. Plast Reconstr Surg 2006; 117 (7 Suppl): 1e-S-32e-S.

25. Simpson DM, Ross R. The neutrophilic leukocyte in wound repair: a study with antineutrophil serum. J Clin Investig 1972; 51: 2009-2023.

26. Oryan A, Zaker S. Effects of topical application of honey on cutaneous wound healing in rabbits. J Veter Med Series A 1998; 45: 181-188.

27. Meszaros AJ, Reichner JS, Albina JE. Macrophage-induced neutrophil apoptosis. J Immunol 2000; 165: 435-441.

28. Nakajima Y, Nakano Y, Fuwano S, Hayashi N, Hiratoko Y, Kinoshita A, Miyahara M, Mochizuki T, Nishino K, Tsuruhara Y, Yokokawa Y, Iuchi T, Kon Y, Mukai K, Kitayama Y, Murakado N, Okuwa M, Nakatani T. Effects of three types of Japanese honey on full-thickness wound in mice. Evid Based Complement Alternat Med 2013; 2013: 504537.

29. Haryanto TU, Mukai K, Suriadi JS, Nakatani T. Effectiveness of Indonesian honey on the acceleration of cutaneous wound healing: an experimental study in mice. Wounds 2012; 24: 110-119.

30. Bingle L, Brown N, Lewis C. The role of tumour-associated macrophages in tumour progression: implications for new anticancer therapies. J Pathol 2002; 196: 254-265.

31. Fukuda M, Kobayashi K, Hirono Y, Miyagawa M, Ishida T, Ejiogu EC, Sawai M, Pinkerton KE, Takeuchi M. Jungle honey enhances immune function and antitumor activity. Evid Based Complement Altern Med 2011; 2011: 908743.

32. Nisbet HO, Nisbet C, Yarim M, Guler A, Ozak A. Effects of three types of honey on cutaneous wound healing. Wounds 2010; 22: 275-283.

33. Molan PC. The role of honey in the management of wounds. J Wound Care 1999; 8: 415-418.

34. Suguna L, Chandrakasan G, Joseph KT. Influence of honey on collagen metabolism during wound healing in rats. J Clin Biochem Nutrition 1992; 13: 7-12.

35. Bulman MW. Honey as a surgical dressing. Middlesex Hosp J 1955; 55: 188-189.

36. Gupta S, Singh H, Varshney A, Prakash P. Therapeutic efficacy of honey in infected wounds in buffaloes. Indian J Animal Sci 1992; 62: 521-523.

37. Subrahmanyam M. A prospective randomised clinical and histological study of superficial burn wound healing with honey and silver sulfadiazine. Burns 1998; 24: 157-161.

38. Mak K, Manji A, Gallant-Behm C, Wiebe C, Hart DA, Larjava $\mathrm{H}$, Hakkinen L. Scarless healing of oral mucosa is characterized by faster resolution of inflammation and control of myofibroblast action compared to skin wounds in the red Duroc pig model. J Dermatol Sci 2009; 56: 168180.

\section{Address for correspondence:}

\section{Leila Golpasandhagh MD}

Department of Periodontology

School of Dentistry

Ahvaz Jundishapur University of Medical Sciences

Ahvaz, Iran

E-mail: lilagolpasand2020@gmail.com 